

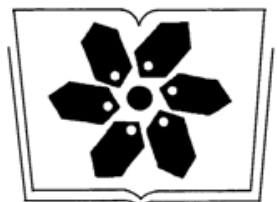

中国科学院科学出版基金资助出版
生 态 学 报

(SHENGTAI XUEBAO)

第 33 卷第 19 期 2013 年 10 月 (半月刊)

中国生态学学会 2013 年学术年会专辑 卷首语

生态系统服务研究文献现状及不同研究方向评述。 马凤娇, 刘金铜, A. Egrinya Eneji (5963) 非人灵长类性打摚行为研究进展 杨斌,王程亮,纪维红,等 (5973) 密度制约效应对啮齿动物繁殖的影响 . 韩群花, 郭 聪, 张美文 (5981) 食物链长度远因与近因研究进展综述 王玉玉,徐军,雷光春 (5990) $\mathrm{AM}$ 真菌在植物病虫害生物防治中的作用机制 罗巧玉，王晓娟，李媛媛，等 (5997) 保护性耕作对农田碳、氮效应的影响研究进展 . 薛建福, 赵 荃金, Shadrack Batsile Dikgwatlhe, 等 (6006) 圈养大熊猫野化培训期的生境选择特征 张明春,黄炎,李德生,等 (6014) 利用红外照相技术分析野生白冠长尾雉活动节律及时间分配 赵玉泽, 王志臣,徐基良,等 (6021) 风速和持续时间对树麻雀能量收支的影响 杨志宏, 吴庆明, 董海燕, 等 (6028) 白马雪山自然保护区灰头小舀鼠的巢址特征 李艳红, 关进科,黎大勇,等 (6035) 生境片段化对千岛湖岛屿上黄足厚结猛蚁遗传多样性的影响 罗媛媛, 刘金亮, 黄杰灵, 等 (6041) 基于 $28 \mathrm{~S}$, COI 和 Cytb 基因序列的薜荔和爱玉子传粉小蜂分子遗传关系研究

吴文珊, 陈友铃, 孙伶俐, 等 (6049) 高榕榕果内 Eupristina 属两种榕小蜂的遗传进化关系 陈友铃, 孙伶例, 武蕾蕾, 等 $(6058)$ 镉胁迫下杞柳对金属元素的吸收及其根系形态构型特征 王树风, 施翔, 孙海菁, 等 (6065) 邻苯二甲酸对萝卜种子萌发、幼苗叶片膜脂过氧化及渗透调节物质的影响

杨延杰, 王晓伟, 赵 康, 等 (6074)

极端干旱区多枝柽柳幼苗对人工水分干扰的形态及生理响应 马晓东, 王明慧, 李卫红, 等 (6081) 贝壳砂生境酸柬叶片光合生理参数的水分响应特征..... 王荣荣,夏江宝,杨吉华,等 (6088) 陶粒覆盖对土壤水分、植物光合作用及生长状况的影响..... 谭雪红, 郭小平, 赵廷宁 (6097) 不同林龄短枝木麻黄小枝单宁含量及养分再吸收动态..... 叶功富, 张尚炬, 张立华,等 (6107)

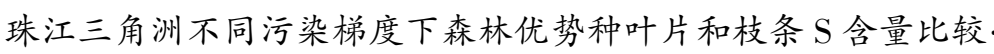
裴男才, 陈步峰, 邹志谨, 等 (6114) $\mathrm{AM}$ 真菌和磷对小马安羊蹄甲幼苗生长的影响 宋成军,曲来叶,马克明, 等 (6121) 盐氮处理下盐地碱蓬种子成熟过程中的离子积累和种子萌发特性............... 周家超,付婷婷, 赵维维,等 (6129) $\mathrm{CO}_{2}$ 浓度升高条件下内生真菌感染对宿主植物的生理生态影响 师志冰, 周 勇, 李 夏, 等 $(6135)$ 预处理方式对香蒲和芦苇种子萌发的影响 孟 焕,王雪宏,佟守正,等 (6142) 镉在土壤-金丝垂柳系统中的迁移特征 雯, 魏 虹, 孙晓灿, 等 (6147) 马尾松人工林近自然化改造对植物自然更新及物种多样性的影响........ 罗应华,孙冬婧,林建勇,等 (6154) 濒危海草贝克喜盐草的种群动态及土壤种子库 以广西珍珠湾为例……

邱广龙,范航清,李宗善,等 (6163)

毛乌素沙地南缘沙丘生物结皮对凝结水形成和蒸发的影响 尹瑞平, 吴永胜, 张 欣, 等 (6173) 塔里木河上游灰胡杨种群生活史特征与空间分布格局…… 韩 路, 席琳乔, 王家强, 等 (6181)

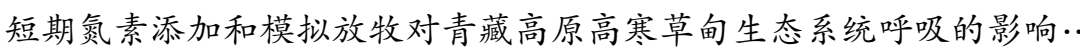
宗宁, 石培礼, 蔣 婧, 等 (6191) 松嫩平原微地形下土壤水盐与植物群落分布的关系 杨 帆,王志春,王云贺,等 (6202) 
广州大夫山雨季林内外空气 TSP 和 $\mathrm{PM}_{2.5}$ 浓度及水溶性离子特征 马鞍列岛岩礁生境鱼类群落结构时空格局…… 黄海细纹狮子鱼种群特征的年际变化. 三种温带森林大型土壤动物群落结构的时空动态 笔管榕榕小蜂的群落结构与物种多样性 海洋生态资本理论框架下的生态系统服务评估 中国地貌区划系统一以自然保护区体系建设为目标..... 生态植被建设对黄土高原农林复合流域景观格局的影响 华北农牧交错带农田-草地景观镶嵌体土壤水分空间异质性 中国北方春小麦生育期变化的区域差异性与气候适应性 中国南方喀斯特石漠化演替过程中土壤理化性质的响应 气候变化对东北沼泽湿地潜在分布的影响…… 内蒙古不同类型草地土壤氮矿化及其温度敏感性 黑河中游荒漠绿洲区土地利用的土壤养分效应 成都平原北部水稻土重金属含量状况及其潜在生态风险评价 大西洋中部延绳钓黄鯺金枪鱼渔场时空分布与温跃层的关系

夏季台湾海峡南部海域上层水体的生物固氮作用 北长山岛森林乔木层碳储量及其影响因子

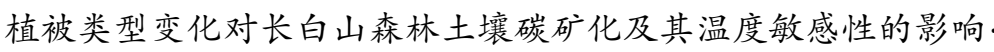
油松遗传结构与地理阻隔因素的相关性 ... 基于辅助环境变量的土壤有机碳空间插值 以黄土丘陵区小流域为例
肖以华, 李昫, 旷远文, 等 (6209) 汪振华, 赵 静, 王 凯, 等 (6218) 陈云龙, 单秀娟, 周志鹏, 等 (6227) . 李 娜, 张雪萍, 张利敏 (6236) 陈友铃, 陈晓倩, 吴文珊, 等 (6246) 陈 尚, 任大川, 夏 涛, 等 (6254) . 郭子良, 崔国发( 6264) 易扬, 信忠保, 覃云斌, 等 (6277) 王红梅, 王仲良, 王 壁, 等 (6287) 俄有浩, 霍治国, 马玉平, 等 (6295) ... 盛茂银, 刘洋, 熊康宁 (6303) 贺伟, 布仁仓, 刘宏娟, 等 (6314) 朱剑兴, 王秋风, 何念鹏, 等 (6320) 马志敏, 吕一河, 孙飞翔, 等 (6328) 秦鱼生, 喻华, 冯文强, 等 (6335) 杨胜龙, 马军杰, 张禹, 等 (6345) 林 峰, 陈 敏, 杨伟锋, 等 (6354) 石洪华, 王晓丽, 王 嫒, 等 (6363) 王丹, 吕瑜良, 徐 丽, 等 (6373) 孟翔翔, 狄晓艳, 王孟本, 等 (6382)

文 雯, 周宝同, 汪亚峰, 等 (6389)

基于生命周期视角的产业资源生态管理效益分析一以虚拟共生网络系统为例

施晓清,李笑诺,杨建新 (6398)

生态脆弱区贫困与生态环境的博弯分析 祁新华, 叶士琳, 程 暗, 等 (6411)

“世博”背景下上海经济与环境的耦合演化 倪 尧, 岳文泽, 张云堂, 等 $(6418)$

期刊基本参数: CN 11-2031/Q * $1981 * \mathrm{~m} * 16 * 464 * \mathrm{zh} * \mathrm{P} * ¥ 90.00 * 1510 * 55 * 2013-10$

封面图说: 毛乌素沙地南缘沙丘的生物结皮一一生物土壤结皮广泛分布于干旱和半干旱区, 它的形成和发育对荒漠生态系统 生态修复过程产生重要的影响。组成生物结皮的藻类、苔藓和地衣是常见的先锋植物, 它们不仅能在严重干旱缺 水、营养贫㾑恶劣的环境中生长、繁殖, 并且能通过其代谢方式影响并改变环境。其中一个重要的特点是, 生物结皮 表面的凝结水显著大于裸沙。研究表明, 凝结水是除降雨之外最重要的水分来源之一, 在水分极度匮乏的荒漠生态 系统, 它对荒漠生态系统结构、功能和过程的维持产生着重要的影响。

彩图及图说提供: 陈建伟教授 北京林业大学 E-mail: cites.chenjw@163.com 
马志敏, 吕一河, 孙飞翔, 王江否. 黑河中游荒漠绿洲区土地利用的土壤养分效应. 生态学报, 2013,33(19):6328-6334.

Ma Z M, Lü Y H, Sun F X, Wang J L.Effects of land use on soil nutrient in oasis-desert ecotone in the middle reach of the Heihe River. Acta Ecologica Sinica, 2013,33(19):6328-6334.

\title{
黑河中游荒漠绿洲区土地利用的土壤养分效应
}

\author{
马志敏，吕一河 ${ }^{*}$, 孙飞翔, 王江否 \\ (中国科学院生态环境研究中心, 北京 100085 )
}

\begin{abstract}
摘要:土地利用影响地表覆被状况和生态过程,关系到土壤肥力与土壤碳库功能 “源-汇”关系的改变。黑河中游甘州区和临泽 县是我国西北干旱区典型的荒漠绿洲区, 以土壤表层 $(0-20 \mathrm{~cm})$ 养分变化为对象,利用 $2011-2012$ 年甘州区和临泽县的土壤 野外调查数据和该区全国第二次土壤普查数据,对两时期土壤表层养分 (土壤有机质、全氮、全磷、全钾及 $\mathrm{pH}$ 值) 的变化特征进 行比较研究。结果表明: 研究区土壤有机质、全磷含量分别降低了 $3.54 \%$ 和 $12.5 \%$; 而全氮、全钾和 $\mathrm{pH}$ 值分别增加了 $74.4 \%$ 、 $98.2 \%$ 和 $4.9 \%$ 。全国第二次土壤普查时期,荒漠、耕地与草地三者在各土壤养分上没有显著差异,但林地在土壤有机质、全氮、 全钾上显著高于前三者。2011-2012 年,耕地土壤的全磷、全氮与其它土地利用存在显著差异。土地利用的保持和改变对土 壤养分变化有着重要影响,耕地的长期耕作使得土壤有机质含量降低 $4.94 \%$,全氮增加 $86.93 \%$,全磷减少 $5.02 \%$, 土壤碱性增 强; 荒漠植被的自然演替使土壤有机质含量增加 $66.21 \%$, 全氮增加 $71.70 \%$, 全磷含量减少 $37.33 \%$, 土壤碱性变弱。所以,耕地 扩张及其长期耕作活动将导致地力退化并有盐碱化风险, 而荒漠等自然生态系统保护有利于土壤肥力的改善和土壤固碳功能 的发挥。
\end{abstract}

关键词:土地利用; 土壤养分变化; 荒漠绿洲区

\section{Effects of land use on soil nutrient in oasis-desert ecotone in the middle reach of the Heihe River}

MA Zhimin, LÜ Yihe* , SUN Feixiang, WANG Jianglei

State Key Laboratory of Urban and Regional Ecology, Research Center for Eco-Environmental Sciences, Chinese Academy of Sciences, Beijing 100085, China

Abstract: Land uses have significant impacts on the changes of land surface covers and ecological processes. Land use type is closely related to the soil fertility and soil carbon pool function. The Ganzhou District and Linze County of Gansu Province, as the typical oasis-desert ecotones, is located in the middle of Heihe River Basin in northwest arid region of China. The topsoil samples were took from the $0-20 \mathrm{~cm}$ depth land surface. The topsoil was sampled at Ganzhou District and Linze County during 2011-2012. The soil nutrients were tested in the laboratory including soil organic matter, total nitrogen, total phosphorus, total potassium and $\mathrm{pH}$. We compared the sampled soil nutrients with the national secondary soil survey data in 1980s which have the similar parameters of soil nutrient and $\mathrm{pH}$.

The results showed that the soil organic matter and total phosphorus decreased by $3.54 \%$ and $12.5 \%$, respectively, during 2011-2012 in comparison to 1980s. Whereas, the soil total nitrogen, soil total potassium and pH increased by 74. $4 \%, 98.2 \%$, and $4.9 \%$. There had no significant differences of soil nutrients among the desert, cropland and meadow in 1980s. However, the soil nutrients of forest were significantly higher than those of the above three land uses such as soil organic matter, soil total nitrogen and soil total potassium. During the period of 2011-2012, the soil total phosphorus, soil total nitrogen of cropland were significantly different from those of the forest, meadow and desert. The results indicated that the long-term farming activity of cropland reduced soil organic matter by $4.94 \%$ and soil total phosphorus by $5.02 \%$, but increased soil total nitrogen by $86.93 \%$ and made soil more alkaline. The results also showed that the desert can increase of

基金项目: 国家自然科学基金重点资助项目 (91025002) ; 国家科技支撑资助项目 (2012BAC08B01)

收稿日期:2013-05-13; 修订日期:2013-07-18

* 通讯作者 Corresponding author.E-mail: lyh@ rcees.ac.cn

http : //www.ecologica.cn 
soil organic matter and soil total nitrogen by $86.93 \%$ and $71.70 \%$ whereas decrease the soil total phosphorus and soil alkalinity as well. Therefore, the cropland expansion and long-term farming activities can lead to the soil fertility degradation coupling with the risk of salinization. However some natural ecological systems, such as the desert, are favor to improve the soil fertility and soil carbon sequestration.

Key Words : land uses; change of soil nutrient; oasis-desert ecotones

土地利用与土地覆被变化是全球环境变化的重要组成部分, 是基于自然环境条件的人类活动的集中反映 ${ }^{[1]}$, 引起生态系 统结构和过程的变化 ${ }^{[2-3]}$, 如地表植被变化影响植被调落物量、生物多样性、地表径流和侵蚀过程、土壤养分和水分的变化以及 生物地球化学循环 ${ }^{[4-6]}$ 等。土地利用变化会引起土壤管理措施的改变, 从而对土壤质量产生影响 ${ }^{[7]}$ 。国内外学者就不同土地 利用方式对土壤质量的影响做了大量工作,一致认为, 不同土地利用方式的变化必然导致土壤性质和土地生产力的改变 ${ }^{[8]}$ 。 傅伯杰等在河北遵化县对土地利用变化与土壤养分变化的关系进行了研究,指出河北遵化县 1980-1999 年大量的旱地转换为 林草地后土壤养分 (有机质、全氮、速效钾、速效磷及速效氮) 全面提高 ${ }^{[9]}$ 。信忠保等在黄土丘陵沟壑区罗玉沟、吕二沟的研究 表明,林地、坡耕地、梯田、果园和草地等五种土地利用方式中, 草地土壤养分最差, 坡耕地的土壤养分(有机质、全氮、全磷、全 钾、速效养分) 都较草地的高 ${ }^{[10]}$ 。土壤养分的变化不仅受到土地利用类型的影响,还因土地利用结构的不同而存在差异。在黄 土丘陵区的研究表明, 从梁底到梁顶的土地利用结构中, 坡耕地一草地一林地、梯田一草地一林地的结构模式具有较好的土壤 保持能力, 其土壤养分的平均含量要高于其它土地利用结构 ${ }^{[11-13]}$ 。此外, 土壤养分变化受到多重因素 (地表覆盖类型、地形地 势、气候、灌溉条件等) 的影响,在不同地区地理气候条件下土壤养分变化呈现多样性特征 ${ }^{[3]}$ 。

西北干旱区位于我国内陆, 其面积较广,生态环境脆弱,在高强度人类活动影响下存在较高的生态退化风险,并且生态系统 一旦退化就难以恢复。甘肃省张掖市的甘州区和临泽县位于西北干旱区的河西走廊, 是典型的荒漠绿洲交错镶嵌的生态结构, 当荒漠开脣为农田绿洲后, 土壤质量会随之发生显著变化 ${ }^{[7]}$ 。刘文杰等对黑河中游绿洲农田土壤速效养分时空变化特征的研 究表明,2008 年土壤速效养分含量比 1982 年有显著提高, 尤其是速效磷增加了 $225.6 \%$,认为土壤缺磷不再是临泽农业生产中 的主要限制因子 ${ }^{[14]}$ 。合理评估土地利用对土壤养分的影响,对于揭示土地利用的生态效应具有重要意义; 探讨土壤养分动态 变化的影响因子对于土壤养分和土壤碳库的科学管理具有积极意义。

土壤养分的相关指标中, 土壤有机质直接影响土壤的保肥性、缓冲性、通气状况和土壤温度,氮、磷、钾是植物生长的必须营 养元素, 是土壤肥力的重要基础 ${ }^{[15]}$ 。土壤酸碱度更是一项重要指标, 反映土壤的酸碱平衡体系, 是土壤养分循环的一个主控因 子 ${ }^{[16]}$ 。本文以黑河中游的张掖市甘州区和临泽县为典型区, 研究土地利用对土壤养分变化的影响, 从整体、土地利用、土地利 用转变或保持三个角度,分析土壤养分中有机质、全氮、全磷、全钾以及土壤 $\mathrm{pH}$ 值对土地利用的响应特征, 探讨土地利用对土 壤养分变化的影响特征及其潜在风险,为土地利用和管理提供科学依据。

\section{1 材料与方法}

\section{1 研究区概况}

研究区是位于甘肃省张掖市的甘州区和临泽县, 地处甘肃省河西走廊中部, 地理范围为东经 $99^{\circ} 51^{\prime}-100^{\circ} 6^{\prime}$, 北纬 $38^{\circ}$ $32^{\prime}-39^{\circ} 42^{\prime}$, 南依祁连山, 北接合黎一龙首山系, 黑河从境内贯穿而过,该区水资源较为丰富、农业发达。四季云量少,光照充 足, 年平均日照时数约为 $3050 \mathrm{~h}$, 年均降雨量约为 $120 \mathrm{~mm}$, 变动范围多在 80-140 mm, 临泽县和甘州区的年均蒸发量分别为 $1830 \mathrm{~mm}$ 和 $2047 \mathrm{~mm}$, 野外样点调查海拔分布范围 1276-2300 $\mathrm{m}$ 。张掖市改革开放以来经济快速增长, 1978 年国民生产总值为 2.52 亿元, 2011 年国民生产总值已经达到 256.84 亿元, 是原来的 100 多倍。研究区内农业经济发达, 是典型的绿洲农业和大型 灌溉农业区,盛产玉米、小麦、豆类、红朰及各种蔬菜, 是全国重点商品粮基地和制种基地。自 20 世纪 80 年代以来,耕地面积持 续扩大, 土地利用格局发生了显著改变, 林地、草地、荒漠被持续地开屋为耕地, 同时耕地、草地、荒漠、林地之间也发生相互 转换。

土地利用方式以耕地为主,绝大部分耕地种植玉米(Zea mays L.) , 少量耕地用于小麦 (Triticum aestivum L.) 、温室蔬菜、葡 萄 (Vitis vinifera) 及药材等的栽培。草地类型主要为山前荒漠草地和滨河湿地草地, 受人为干扰和破坏程度较小, 优势种为芦苇 (Phragmites australis (cav.) Trin. ex Steud.) 和苣荬菜( Sonchus arvensis Linn.), 其土壤类型以灌漠土、荒漠风沙土、灰棕漠土等为 主。林地类型包括旱地林场、滨河树林和人工种植的林地 3 种类型, 旱地林场的主要树种为小叶杨 (Populus simonii Carr.) 和沙 妻( Elaeagnus angustifolia Linn.), 滨河树林建群植被有红柳( Tamarix ramosissima Ledeb.) 、小叶杨和沙苯, 人工种植林地则以小 叶杨、新疆杨 (Populus alba Linn.var. pyramdalis Bunge) 为主。荒漠则多分布于绿洲周边和龙首山周边, 前者植被稀少,地表多有 少许石砾, 后者分布海拔较高, 在 $1700 \mathrm{~m}$ 以上; 荒漠典型特点是土壤较干, 植被以珍珠猪毛菜 (Salsola passerina Bunge) 和合头草 (Sympegma regelii Bunge) 为主。 


\section{2 数据来源与方法}

2011-2012 年野外布点采集土样, 从南部的祁连山山前到北部的龙首一合黎山,在荒漠绿洲区选择典型的耕地、林地、荒 漠等类型布点采样,共布设 53 个样地(图 1)。每个样地利用 GPS 记录经纬度,收集表层 0-20 cm 的土壤, 在样地不同位置重 复取土样 3 次,装人布袋, 并做标记, 带回实验室风干, 过 100 目篮子, 测定土壤全量养分, 包括有机质、全氮、全磷、全钾和 $\mathrm{pH}$ 值。

收集甘州区 (1980)、临泽县 (1982) 的全国第二次土壤普查 数据得到的黑河流域 1:100 万土壤类型数据集,该 1:100 万土壤 数据图编制工作始于 1986 年, 其中属性表里的土壤表层养分属 性包括有机质、全氮、全钾、全磷和酸碱度。全国第二次土壤普 查时, 土壤有机质采用重铬酸钾法测定, 采用的介质是液体石蜡 油,在高温 $185-190{ }^{\circ} \mathrm{C}$ 条件下,用过量的标准重铬酸钾-浓硫酸 溶液氧化土壤中有机碳, 加邻菲罗啉指示剂后, 用硫酸亚铁溶液 滴定多余重铬酸钾; 土壤全氮采用的是高氯酸-浓硫酸硝化后, 光 电比色测定; 土壤全磷同样采用高氯酸-浓硫酸消解体系, 外加钼 锑抗显色剂, 光电比色测定; 土壤全钾采用 $\mathrm{CaCO}_{3}-\mathrm{NH}_{4} \mathrm{CL}$ 焙烧, 用火焰光度计测定其水浸提液; 土壤酸碱度用 $5: 1$ 水土比与永久 色阶进行比色测定或通过电位法测定 ${ }^{[17]}$ 。收集黑河中游 1986 年 1:10 万土地利用数据集中的矢量数据, 采用中国科学院土地 利用分类标准,该数据集剪裁于 1986 年中国 1:10 万土地利用数 据集, 同时收集黑河中游 2000、2005、2007 年三期的土地利用矢 量数据。

1.3 土壤样品测试方法 ${ }^{[18]}$

土壤 $\mathrm{pH}$ 值用 $\mathrm{pH}$ 计测定, 具体方法是测定常温下以 5:1 的 水土质量比例溶于规格为 $50 \mathrm{~mL}$ 烧杯中 (土壤 $5 \mathrm{~g}$, 去离子水 25 $\mathrm{mL}$ ), 用玻璃棒搅拌使其溶解, 静置, 取其上清液与玻璃试管中,

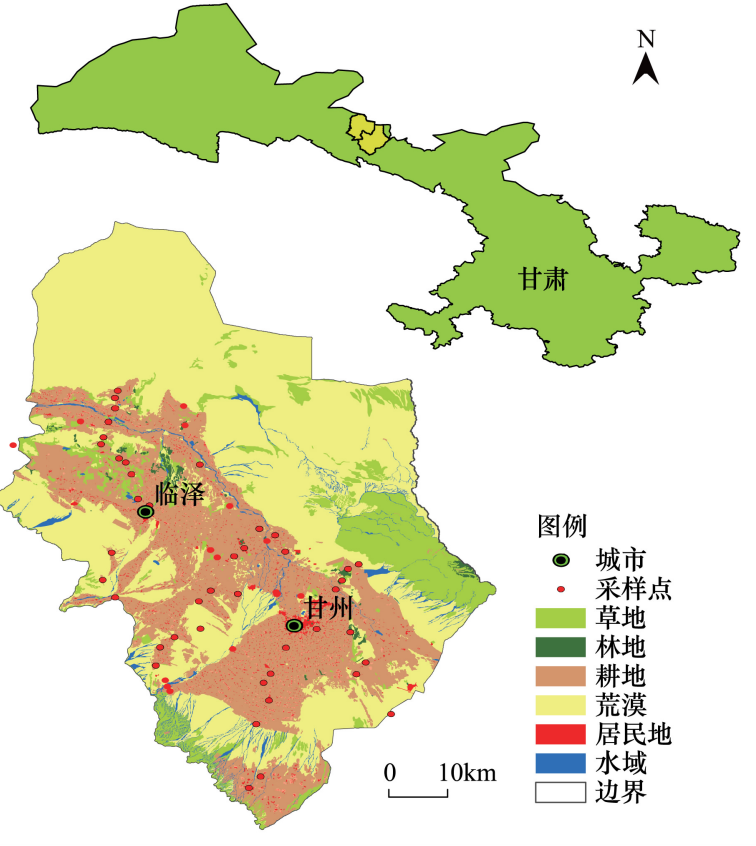

图 1 研究区位置及样地分布

Fig.1 The location of study areas and distribution of sample plots 用标准试剂液校准(两点校正) 过的 $\mathrm{pH}$ 计测定。土壤有机质用 重铬酸钾外加热法测定,具体为称取 $0.5 \mathrm{~g} 100$ 目土壤于 $50 \mathrm{~mL}$ 的比色管中,加人 $5 \mathrm{~mL}$ 浓度为 $0.800 \mathrm{~mol} / \mathrm{L}$ 的重铬酸钾标准液和 $5 \mathrm{~mL}$ 浓硫酸, 置于试管架上, 在烘箱中于 $105^{\circ} \mathrm{C}$ 下加热 $10 \mathrm{~min}$ 中, 冷却后, 从试管移人雉形瓶中, 加人邻菲罗林指示剂 2 - 3 滴, 用浓度为 $0.2 \mathrm{~mol} / \mathrm{L}$ 的硫酸亚铁溶液滴定。土壤全氮用德国 Vario EL III 元素分析仪测得, 具体为称取 $30 \mathrm{mg}$ 的 100 目土壤于专 用的锡舟中,包好后放于分析仪的转盘内,所用的标准土样为 GSS- 8 。全磷和全钾用( ICP-OES) 同时测定,具体为称取 $0.1 \mathrm{~g}$ (精 确到 $0.001 \mathrm{~g}$ ) 100 目土壤于聚四氟乙烯坩埚中,依次加人各种酸后再电热板上消煮,消煮体系为硝酸-高氯酸-氢氟酸-盐酸,消煮 方法采用的是国家标准 GB 9836- 88, 钾测定采用的分析线波长为 $766.491 \mathrm{~nm}$, 磷测定采用的分析线波长为 $214.914 \mathrm{~nm}$ 。

1.4 数据分析方法

利用 ArcGIS 9.3 生成采样点的图层,叠置于全国第二次土壤普查黑河流域 $1: 100$ 万土壤数据集上,得到样点处 80 年代初 的表层土壤养分值,结合实际测定土壤养分数据,对比分析 30 年耕层土壤养分的变化; 结合研究区 1986、2000、2005 和 2007 年 4 期土地利用数据集来比对样点尺度 30 年来土地利用类型变化对土壤养分的影响。基于(PASW) 18.0 软件进行土壤养分特 征的分析。运用单因素方差分析( One-way ANOVA) 来检验土地利用间土壤养分变化的显著性。

\section{2 结果与分析}

2.1 研究区内土壤养分的总体变化

研究区土壤养分的总体情况如表 1 所示。全国第二次土壤普查时,研究区表层 $(0-20 \mathrm{~cm})$ 土壤有机质、全氮、全磷、全钾的 平均值依次为 $15.83 、 0.91 、 0.80 、 20.14 \mathrm{~g} / \mathrm{kg}, \mathrm{pH}$ 值 8.3 。在 5 项土壤指标中, 土壤 $\mathrm{pH}$ 值变异系数最小, 仅为 0.038 , 变异系数最大 的为土壤有机质、全氮,变异系数大小分别为 0.63 和 0.59 。这表明 80 年代初, 研究区内土壤有机质含量比较低,氮、磷俱缺, 土 壤钾相对丰富 ${ }^{[19]}$ 。2011-2012 年, 土壤有机质、全氮、全磷和全钾的平均值分别为 $15.27 、 1.59 、 0.71 \mathrm{~g} / \mathrm{kg}$ 和 $40.03 \mathrm{~g} / \mathrm{kg}$, 它们的 变异系数分别为 $0.34 、 0.37 、 0.41 、 0.04$, 同时土壤的 $\mathrm{pH}$ 值平均值为 8.65 ,变异系数为 0.024 。30 年来,研究区土壤有机质、全磷分 别降低了 $3.54 \% 、 12.5 \%$, 而全氮和全钾及 $\mathrm{pH}$ 值分别增加了 $74.7 \% 、 98.2 \%$ 与 $4.9 \%$ 。土壤中有机质含量减少了 $0.56 \mathrm{~g} / \mathrm{kg}$, 而土壤 全氮和全钾的含量大幅增加, 土壤碱性增强。

2.2 不同土地利用的土壤养分特征

研究区内不同土地利用的土壤养分情况如表 2 所示。 
表 1 研究区两个时期土壤养分及其变化情况统计

Table 1 Statistics of soil nutrients and the variation in study area of two periods

\begin{tabular}{|c|c|c|c|c|c|c|}
\hline $\begin{array}{l}\text { 年份 } \\
\text { Year }\end{array}$ & $\begin{array}{l}\text { 指标 } \\
\text { Indices }\end{array}$ & $\begin{array}{l}\text { 平均值 } \\
\text { Average }\end{array}$ & $\begin{array}{c}\text { 最大值 } \\
\text { Maximum }\end{array}$ & $\begin{array}{c}\text { 最小值 } \\
\text { Minimum }\end{array}$ & $\begin{array}{l}\text { 标准差 } \\
\text { Standard } \\
\text { deviation }\end{array}$ & $\begin{array}{c}\text { 变异系数 } \\
\text { Variable } \\
\text { coefficient }\end{array}$ \\
\hline \multirow[t]{5}{*}{$1980-1981$} & 有机质 Organic matter $/(\mathrm{g} / \mathrm{kg})$ & 15.83 & 38.1 & 3.6 & 9.97 & 0.63 \\
\hline & 全氮 Total nitrogen/(g/kg) & 0.91 & 2.02 & 0.22 & 0.54 & 0.59 \\
\hline & 全磷 Total phosphorus/(g/kg) & 0.80 & 1.19 & 0.25 & 0.27 & 0.34 \\
\hline & 全钾 Total potassium/ $(\mathrm{g} / \mathrm{kg})$ & 20.14 & 28.0 & 15.4 & 3.12 & 0.15 \\
\hline & $\mathrm{pH}$ 值 $\mathrm{pH}$ value & 8.3 & 8.9 & 7.6 & 0.32 & 0.038 \\
\hline \multirow[t]{5}{*}{$2011-2012$} & 有机质 Organic matter $/(\mathrm{g} / \mathrm{kg})$ & 15.27 & 28.18 & 5.04 & 5.14 & 0.34 \\
\hline & 全氮 Total nitrogen/(g/kg) & 1.59 & 2.83 & 0.33 & 0.59 & 0.37 \\
\hline & 全磷 Total phosphorus/(g/kg) & 0.71 & 1.26 & 0.15 & 0.29 & 0.41 \\
\hline & 全钾 Total potassium/ $(\mathrm{g} / \mathrm{kg})$ & 40.03 & 44.6 & 36.14 & 1.58 & 0.04 \\
\hline & $\mathrm{pH}$ 值 $\mathrm{pH}$ value & 8.65 & 9.44 & 8.13 & 0.206 & 0.024 \\
\hline \multirow[t]{5}{*}{ 变化量 Change } & 有机质 Organic matter $/(\mathrm{g} / \mathrm{kg})$ & -0.56 & 24.58 & -33.06 & 10.94 & \\
\hline & 全氮 Total nitrogen/(g/kg) & 0.68 & 2.05 & -1.09 & 0.73 & \\
\hline & 全磷 Total phosphorus/(g/kg) & -0.10 & 0.56 & -0.77 & 0.32 & \\
\hline & 全钾 Total potassium/ $(\mathrm{g} / \mathrm{kg})$ & 19.77 & 27.50 & 11.73 & 3.35 & \\
\hline & $\mathrm{pH}$ & 0.41 & 1.18 & -0.27 & 0.37 & \\
\hline
\end{tabular}

表 2 不同土地利用类型土壤养分不同时期的对比

Table 2 Contrast of soil nutrients under different land use types between different periods

\begin{tabular}{|c|c|c|c|c|c|c|c|}
\hline $\begin{array}{l}\text { 年份 } \\
\text { Year }\end{array}$ & $\begin{array}{l}\text { 土地利用 } \\
\text { Land use }\end{array}$ & $\begin{array}{c}\mathrm{N} \\
\text { Number }\end{array}$ & $\begin{array}{c}\text { 有机质/ ( g/kg) } \\
\text { Organic matter }\end{array}$ & $\begin{array}{l}\text { 全氮/(g/kg) } \\
\text { Total nitrogen }\end{array}$ & $\begin{array}{l}\text { 全钾/ }(\mathrm{g} / \mathrm{kg}) \\
\text { Total potassium }\end{array}$ & $\begin{array}{l}\text { 全磷/( g/kg) } \\
\text { Total phosphorus }\end{array}$ & $\begin{array}{c}\mathrm{pH} \text { 值 } \\
\mathrm{pH} \text { value }\end{array}$ \\
\hline \multirow[t]{4}{*}{$1980-1982$} & 荒漠 Desert & 6 & $12.30 \pm 13.3 \mathrm{~b}$ & $0.65 \pm 0.58 b$ & $19.22 \pm 3.68 b$ & $0.60 \pm 0.23$ & $8.36 \pm 0.43$ \\
\hline & 耕地 Cropland & 27 & $16.74 \pm 6.97 \mathrm{~b}$ & $1.01 \pm 0.48 \mathrm{ab}$ & $19.94 \pm 1.86 \mathrm{ab}$ & $0.91 \pm 0.24$ & $8.31 \pm 0.21$ \\
\hline & 林地 Forest & 4 & $28.47 \pm 11.1 \mathrm{a}$ & $1.35 \pm 0.49 \mathrm{a}$ & $23.0 \pm 4.44 \mathrm{a}$ & $0.63 \pm 0.17$ & $7.60 \pm 0$ \\
\hline & 草地 Meadow & 13 & $12.59 \pm 10.82 b$ & $0.74 \pm 0.57 \mathrm{ab}$ & $19.48 \pm 3.19 \mathrm{a}$ & $0.73 \pm 0.26$ & $8.27 \pm 0.33$ \\
\hline \multirow[t]{3}{*}{$2011-2012$} & 荒漠 Desert & 10 & $15.66 \pm 3.80$ & $1.23 \pm 0.47 b$ & $41.19 \pm 1.12 \mathrm{~A}$ & $0.44 \pm 0.18 \mathrm{~B}$ & $8.59 \pm 0.25$ \\
\hline & 耕地 Cropland & 36 & $14.77 \pm 5.03$ & $1.76 \pm 0.54 \mathrm{a}$ & $39.42 \pm 1.32 \mathrm{~B}$ & $0.86 \pm 0.22 \mathrm{~A}$ & $8.66 \pm 0.16$ \\
\hline & 林地 Forest & 7 & $17.82 \pm 7.26$ & $1.39 \pm 0.63 \mathrm{ab}$ & $41.36 \pm 1.86 \mathrm{~A}$ & $0.40 \pm 0.10 \mathrm{~B}$ & $8.71 \pm 0.35$ \\
\hline
\end{tabular}

采用 Duncan 多重极差检验法, 大写字母代表 0.01 水平检验结果, 小写字母代表 0.05 检验结果, 无标记的表示差异不显著

(1) 土壤有机质变化 全国第二次土壤普查时, 表层土壤有机质含量最高的是林地 $(28.47 \mathrm{~g} / \mathrm{kg})$, 耕地 $(16.74 \mathrm{~g} / \mathrm{kg})$ 次之, 其后为草地 $(12.59 \mathrm{~g} / \mathrm{kg})$, 荒漠 $(12.3 \mathrm{~g} / \mathrm{kg})$ 最小。林地土壤有机质显著高于其他土地利用类型, 而耕地、草地和荒漠之间土壤 有机质含量没有显著差异; 就土壤有机质的标准差大小而言, 荒漠 (13.3) > 林地 (11.1) > 草地 (10.82) > 耕地 (6.97), 荒漠土壤 有机质变异性最大,耕地土壤有机质变异性最小。2011-2012 年时, 林地表层 $(0-20 \mathrm{~cm})$ 平均土壤有机质含量为 $17.82 \mathrm{~g} / \mathrm{kg}$, 荒漠为 $15.66 \mathrm{~g} / \mathrm{kg}$, 耕地为 $14.77 \mathrm{~g} / \mathrm{kg}$, 其标准差大小为林地 $(7.26)>$ 耕地 $(5.03)>$ 荒漠 $(3.80) 。 30$ 年来, 林地和耕地的土壤 有机质呈下降趋势,而荒漠的土壤有机质则呈累积效应,并且区内荒漠土壤有机质的变异性减少最为明显。

(2) 土壤全氮、全磷、全钾的变化 全国第二次土壤普查时,土壤全氮、全钾在土地利用间呈现相同趋势,林地 > 耕地 > 草 地 > 荒漠; 土壤全磷的大小特点为耕地含量最高, 草地次之, 其后为林地, 荒漠的土壤全磷最小; 土壤全磷的标准差在 $0.17-$ 0.26 之间,土壤全钾的标准差变动范围是 1.86-4.44,土壤全氮的标准差在 $0.48-0.57$ 之间。2011-2012 年时,表层土壤全氮、 全磷、全钾在各土地利用间的大小关系较全国第二次土壤普查时期发生了改变。土壤全氮含量大小次序为耕地 $>$ 林地 $>$ 荒 漠, 土壤全钾的大小次序为林地 $>$ 荒漠 $>$ 耕地, 土壤全磷的含量大小次序为耕地 $>$ 荒漠 $>$ 林地。从时间上比较, 耕地和荒漠 的土壤全氮和全钾含量增加明显、土壤全磷稍微降低, 而林地的土壤全钾含量增加, 但土壤全氮和全磷含量都减少, 流失较为 突出。

(3) 土壤 $\mathrm{pH}$ 值变化 各土地利用间的土壤 $\mathrm{pH}$ 值相差不大。全国第二次土壤普查时, 林地 $(7.6)<$ 耕地 $(8.31)<$ 草地 (8. 27) <荒漠 (8.36), 荒漠土壤 $\mathrm{pH}$ 值最大, 林地土壤 $\mathrm{pH}$ 值最小; $2011-2012$ 年时, 区内土壤 $\mathrm{pH}$ 值呈增大趋势, 土壤表层趋向 碱性变化, 荒漠 $(8.59)<$ 耕地 $(8.66)<$ 林地 $(8.71)$, 并且林地、耕地的土壤 $\mathrm{pH}$ 值趋碱性程度较荒漠更强。 
2.3 样地尺度土地利用变化的土壤养分效应

样地尺度上,比较土地利用保持不变或者发生改变后的土壤养分变化趋势来揭示土地利用对土壤养分变化的直接影响。 根据野外调查样地经纬度信息和土地利用类型以及 1986 年土地利用数据, 确定土地利用变化类型是维持还是改变。选取耕 地-耕地、荒漠-荒漠、草地-耕地、草地-荒漠和草地-林地 5 种典型土地利用变化类型来比较其土壤养分变化特点 (表 3 )。如 “耕 地-耕地” 表示全国第二次土壤普查时的土地利用类型和 2011-2012 年的土地利用类型相同,均为耕地, 同理, 草地-耕地表示 全国第二次土壤普查时草地类型转变成了 2011-2012 年的耕地。

不同土地利用变化类型有着不同的土壤养分变化效应, 土壤有机质增加的土地利用变化类型按增加量大小排列依次为荒 漠-荒漠、草地-荒漠和草地-耕地, 土壤有机质平均增量依次为 $5.23 \mathrm{~g} / \mathrm{kg} 、 4.25 \mathrm{~g} / \mathrm{kg}$ 和 $1.51 \mathrm{~g} / \mathrm{kg}$, 耕地-耕地维持类型土壤有机质 减少 $0.85 \mathrm{~g} / \mathrm{kg}$ 、草地-林地变化类型土壤有机质平均减少 $10.30 \mathrm{~g} / \mathrm{kg}$ 。耕地-耕地土壤全氮增加量最大, 为 $0.91 \mathrm{~g} / \mathrm{kg}$, 草地-耕地 土壤全氮增加量为 $0.73 \mathrm{~g} / \mathrm{kg}$, 草地-荒漠土壤全氮增加量为 $0.62 \mathrm{~g} / \mathrm{kg}$, 荒漠-荒漠土壤全氮增量最小, 为 $0.33 \mathrm{~g} / \mathrm{kg}$, 相反, 草地-林 地的土壤全氮减少了 $0.10 \mathrm{~g} / \mathrm{kg}$ 。按土壤全钾的变化量大小依次荒漠-荒漠、草地-荒漠、耕地-耕地、草地-耕地和草地-林地, 前 4 种土地利用变化类型间的土壤全钾变化量没有显著差异,荒漠-荒漠和草地-荒漠的土壤全钾变化量要极显著地高于草地-林地。

5 种土地利用变化类型中, 唯草地-耕地的土壤全磷增加, 增量为 $0.15 \mathrm{~g} / \mathrm{kg}$, 其它土地利用变化类型的土壤全磷含量减少, 减少最多的为草地-荒漠, 土壤全磷减少量为 $0.45 \mathrm{~g} / \mathrm{kg}$, 荒漠-荒漠的土壤全磷减少量为 $0.24 \mathrm{~g} / \mathrm{kg}$, 草地-林地土壤全磷减少 0.16 $\mathrm{g} / \mathrm{kg}$, 耕地-耕地的土壤全磷减少量最小, 仅为 $0.05 \mathrm{~g} / \mathrm{kg}$, 并且唯有草地-耕地与草地-荒漠土壤全磷变化量差异显著。土壤 $\mathrm{pH}$ 值变化在土地利用变化类型中也有明显差异, 草地-林地土壤 $\mathrm{pH}$ 值增大了 0.82 , 耕地-耕地土壤 $\mathrm{pH}$ 值增大了 0.39 , 而荒漠-荒漠 土壤 $\mathrm{pH}$ 值则减少了 0.12 ,这 3 种土地利用变化类型间土壤 $\mathrm{pH}$ 值变化量存在极显著差异。

\section{表 3 基于样地的土地利用维持或改变后土壤养分的变化量}

Table 3 The variation of soil nutrients with land use condition based on field plots

\begin{tabular}{|c|c|c|c|c|c|c|}
\hline $\begin{array}{l}\text { 土地利用情况 } \\
\text { Land use condition }\end{array}$ & $\begin{array}{c}\text { 株数 } \\
\text { Number }\end{array}$ & $\begin{array}{c}\text { 有机质/ ( g/kg) } \\
\text { Organic matter }\end{array}$ & $\begin{array}{l}\text { 全氮/( g/kg) } \\
\text { Total nitrogen }\end{array}$ & $\begin{array}{c}\text { 全钾 } /(\mathrm{g} / \mathrm{kg}) \\
\text { Total potassium }\end{array}$ & $\begin{array}{c}\text { 全磷/(g/kg) } \\
\text { Total phosphorus }\end{array}$ & $\mathrm{pH}$ \\
\hline 耕地-耕地 Cropland-Cropland & 26 & -0.85 & 0.91 & $19.61 \mathrm{ABC}$ & $-0.05 a b$ & $0.39 \mathrm{~B}$ \\
\hline 荒漠-荒漠 Desert-Desert & 4 & 5.23 & 0.33 & $22.92 \mathrm{~A}$ & $-0.24 \mathrm{ab}$ & $-0.12 \mathrm{C}$ \\
\hline 草地-耕地 Meadow-Cropland & 7 & 1.51 & 0.73 & $19.22 \mathrm{ABC}$ & $0.15 \mathrm{a}$ & $0.44 \mathrm{AB}$ \\
\hline 草地-荒漠 Meadow-Desert & 4 & 4.25 & 0.62 & $22.67 \mathrm{AB}$ & $-0.45 b$ & $0.46 \mathrm{AB}$ \\
\hline 草地-林地 Meadow-Forest & 2 & -10.30 & -0.10 & $17.19 \mathrm{C}$ & $-0.16 a b$ & $0.82 \mathrm{~A}$ \\
\hline
\end{tabular}

采用 Duncan 多重极差检验法, 大写字母代表 0.01 水平检验结果, 小写字母代表 0.05 检验结果,无标记的表示差异不显著

耕地-耕地与荒漠-荒漠,这两种土地利用保持的土壤养分效应有着截然不同的特点, 前者土壤有机质含量减少, 后者明显 增加; 前者土壤 $\mathrm{pH}$ 值增大碱性增强, 后者土壤 $\mathrm{pH}$ 值减小趋于脱碱; 两者的全氮、全钾都增加, 但前者全氮的增加要大于后者, 前者土壤全钾的增加小于后者, 同时全磷都减小,但前者的效应弱于后者。

草地-耕地与草地-荒漠是草地的两种土地利用变化类型, 草地-耕地土壤全磷含量增加 $0.15 \mathrm{~g} / \mathrm{kg}$, 但草地-荒漠土壤全磷含 量减少 $0.45 \mathrm{~g} / \mathrm{kg}$; 草地-荒漠的土壤有机质增长效应强于草地-耕地, 在全氮和全钾上两者都有增加, 草地-耕地土壤全氮增量大 于草地-荒漠,但前者的土壤全钾增量小于后者,两者土壤 $\mathrm{pH}$ 值都增加,分别增加了 0.44 和 0.46 。

\section{3 讨论}

土地利用是环境属性的综合反映, 由不同土地利用构成的异质景观影响土壤养分的分布和迁移 ${ }^{[12]}$ 。与分析不同土地利用 的土壤养分大小相比, 土地利用方式对土壤养分的长期时间效应更值得关注和探讨。本研究的结果表明,黑河中游荒漠绿洲 区,耕地长期利用造成土壤养分的变化,土壤中全氮、全钾含量增加, 土壤有机质含量下降, 土壤 $\mathrm{pH}$ 值增大; 荒漠自然演替使得 土壤有机质的含量平均提升了 $5.23 \mathrm{~g} / \mathrm{kg}$, 同时土壤 $\mathrm{pH}$ 值下降了 0.12 。这说明荒漠区灌丛植被定居和演替对土壤化学性状具 有明显的改变。土壤理化性状的改变既是植被对土壤的作用,也是影响植被演替方向的重要因素 ${ }^{[20]}$ 。

土地利用发生变化后,土壤养分含量在时间和空间上发生改变。王根绪等在黑河流域中游土地利用变化的环境影响研究 中表明,草地转变为耕地 $3 \mathrm{a}$ 后, $0-20 \mathrm{~cm}$ 土层土壤有机质与全氮含量略有减少; 耕种 $10 \mathrm{a}$ 以上, $0-50 \mathrm{~cm}$ 土层土壤有机质和 全氮含量大幅度减少, 逐渐形成亚稳态 ${ }^{[21]}$ 。原因是土地利用的改变伴随着人类对土地的作用方式和强度的变化。草地转变为 耕地, 伴随翻耕、施肥和灌溉等农业管理措施, 有机物降解加快, 消耗加剧, 土壤中有机质含量降低, 同时化肥大量使用使得土壤 的全钾、全氮含量升高, 土壤 $\mathrm{pH}$ 值增加。草地转化为荒漠, 水分减少, 土壤渐干,较为抗旱的植被代替原来的草地植被,生长缓 慢、消耗养分较少, 荒漠植被低叶面积,适口性差, 高比例的土壤枝叶调落物 ${ }^{[22]}$, 使得土壤养分含量增加。

可见, 荒漠绿洲区耕地开垦后, 在粗放的管理模式下,随着耕作管理时间的延长, 土壤质量发生退化, 突出地表现为土壤有 
机质减少, 碱化程度升高, 这将对农田生态系统的可持续管理带来重要挑战。因此,控制农田扩张、改善农田的水肥管理 ${ }^{[23]}$ 对 于维系荒漠绿洲区的农田生态系统健康非常重要。相反,荒漠生态系统作为少受人为干扰的生态系统类型, 其自然演替能够促 进土壤养分积累, 表现出显著的土壤固碳效应, 同时, 碱化程度降低。所以, 从维持荒漠绿洲区生态健康的角度, 有必要加大荒 漠生态系统的保护和恢复。

土壤养分变化动态不仅取决于土地利用的变化还受到土壤类型的影响。表 3 中的草地-林地转换, 土壤有机质降低了 $10.30 \mathrm{~g} / \mathrm{kg}$, 经过 2000、2005、2007 年三期土地利用数据比对可以发现, 从 1986 年至 2007 年一直是草地, 直接原因是两个样点 位的土壤类型不同, 即土壤养分的初始状态不同,一个为荒漠风沙土,一个为石灰性草甸土,草地转变为林地土壤养分效应,在 荒漠风沙土上增加累积,在石灰性草甸土上下降。Bellamy 等在研究英格兰和苏格兰 1978-2003 年土壤碳库变化时发现, 土壤 有机碳的变化率与土地利用、降雨类型、土壤质地类型不存在统计上的显著相关关系,但是土壤有机碳改变速率与初始有机碳 含量呈显著线性负相关关系 ${ }^{[12]}$ 。即土壤养分的损失, 特别是土壤有机质的损失与土壤的初始状态紧密关联,一定程度上土壤 类型影响土壤养分的变化。另外土壤养分中的氮的循环还受到土壤 $\mathrm{pH}$ 值的影响。Cheng 等在加拿大亚伯达省中部利用氮- 16 同位素示踪技术研究发现土壤 $\mathrm{pH}$ 值增加促使氮素矿化 ${ }^{[8]}$, 这说明土壤 $\mathrm{pH}$ 值增加,一定程度上可能加剧了土壤有机物的分解。

\section{4 结论}

整体上,2011-2012 年表层土壤养分含量较全国第二次土壤普查 20 世纪 80 年代时, 土壤有机质、全磷含量分别降低了 $3.54 \%$ 和 $12.5 \%$, 土壤全氮增加了 $74.4 \%$, 土壤全钾近乎翻番, 土壤 $\mathrm{pH}$ 值上升 $4.9 \%$ 。

表层土壤养分的时间动态因土地利用不同而异, 对土壤有机质而言,耕地的长期耕作导致土壤有机质显著降低,而荒漠生 态系统的土壤有机质累积效果明显,表现出良好的土壤固碳效应, 表明荒漠有较高的长期固碳潜力; 荒漠和耕地土壤中都呈现 全氮含量的增加,但来源不同, 荒漠的全氮增量来源于含氮有机物, 耕地的全氮增量则来源于化肥的施用; 耕地土壤持续碱化, 荒漠土壤 $\mathrm{pH}$ 值在减小。土地利用转换对土壤养分变化具有驱动效应, 但也要注意土壤类型和土地利用转换对土壤养分的耦 合影响。

本研究表明,尽管我国西北荒漠绿洲区人口和经济社会发展的压力日益增加,自然生态系统的保护和恢复仍然是必须强化 和长期坚持的重要工作,关系到区域生态安全的维持。严格控制耕地向自然、半自然生态系统的扩张,大力提升农田经营管理 水平, 是实现区域农业和国民经济健康持续发展的重要基础。

\section{References:}

[ 1 ] Wang F, Xiao H L, Song Y Z, Fan G P. Changes of soil quality after reclamation in oasis saline meadow in Linze, Gansu, China. Journal of Desert Research, 2011, 31(3): 723-727.

[ 2 ] Kong X B, Zhang F R, Qi W, Xu Y. The influence of land use change on soil fertility in intensive agricultural region: A case study of Quzhou County, Hebei. Acta Geographica Sinica, 2003, 58(3): 333-342.

[ 3 ] Yang L Y, Qu J Y, Wu X H. Research progress of the effects of different land use types on soil nutrients in China. Journal of Anhui Agricultural Sciences, 2012, 40(18): 9693-9696.

[ 4 ] Fu B J, Chen L D, Ma K L, Zhou H F, Wang J. The relationships between land use and soil conditions in the hilly area of the Loess Plateau in northern Shaanxi, China. Catena, 2000, 39(1): 69-78.

[ 5 ] Post W M, Kwon K C. Soil carbon sequestration and land-use change: Processes and potential. Global Change Biology, 2000, 6(3): 317-328.

[ 6 ] Islam K R, Weil R R. Soil quality indicator properties in mid-Atlantic soils as influenced by conservation management. Journal of Soil Water Conservation, 2000, 50(1): 226-228.

[ 7 ] Zhang S Q, Sun X F. Characteristics of nitrogen, phosphorus and potassium nutrients of arable soil in Gansu. Chinese Journal of Soil Science, 2006, 37(1): 13- 18 .

[ 8 ] Islam K R, Weil R R. Land use effects on soil quality in a tropical forest ecosystem of Bangladesh. Agriculture, Ecosystem and Environment, 2000, $79(1): 9-16$.

[ 9 ] Fu B J, Guo X D, Chen L D, Ma K M, Li J R. Land use changes and soil nutrient changes: A case study in Zunhua County, Hebei Province. Acta Ecologica Sinica, 2001, 21(6): 926-931.

[10] Xin Z B, Yu X X, Zhang M L, Li Q Y, Li H G. Soil nutrient characteristics under different land use types in a gully-hilly region of the Loess Plateau. Arid Zone Research, 2012, 29(3): 379-394.

[11] Fu B J, Ma K M, Zhou H F, Chen L D. Effects of land use structure on distribution of soil nutrients in a gully-hilly region of Loess Plateau. Chinese Science Bulletin, 1998, 43(22) : 2444-2448.

[12] Fu B J, Chen L D, Wang J, Meng Q H, Zhao W W. Land use structure and ecological processes. Quaternary Sciences, 2003, 23(3) : $247-255$.

[13] Liu Q Y, Tong Y P. Effects of land use type on soil nutrient distribution in northern agro-pasture ecotone. Chinese Journal of Applied Ecology, $2005,16(10): 1849-1852$.

[14] Liu W J, Su Y Z, Yang R, Fan G P, Yang Q. Characteristics of spatio-temporal changes of soil organic matter in typical oasis croplands of Linze 
County at middle reaches of Heihe River. Arid Land Geography, 2010, 33(2): 170-176.

[15] Zhao R F, Zhang Y G, Zhang Q, Cheng B, Zhang J J. Effects of different land use types on soil nutrients conditions in cultivated land-A case study of Taiyuan. Chinese Agricultural Science Bulletin, 2011, 27(14) : 262-266.

[16] Cheng Y, Wang J, Mary B. Soil pH has contrasting effects on gross and net nitrogen mineralizations in adjacent forest and grassland soils in central Alberta, Canada. Soil Biology and Biochemistry, 2013, 57: 848-857.

[17] Chang Z H. Routine analysis of soil survey projects and methods. Xinjiang Agriculture Sciences, 1979, (2): $31-33$.

[18] Lu R K. Analysis Methods of Soil Agricultural Chemistry. Beijing: China Agricultural Science Press, 2000.

[19] Wang F, Xiao H L, Su Y Z, Fan G P. Effects of land use type on soil quality in marginal oasis of the middle Heihe River. Journal of Arid Land Resources and Environment, 2010, 24(7): 165-170.

[20] Zhao H L, Su Y Z, Zhou R L. Restoration mechanism of degraded vegetation in sandy areas of Northern China. Journal of Desert Research, 2006, $26(3): 323-328$.

[21] Wang G X, Ma H Y, Wang Y B, Chang J. Impacts of land use change on environment in the middle reaches of the Heihe River. Journal of Glaciology and Geocryology, 2003, 25(4): 359-367.

[22] Wardle D A, Bardgett R D, Klironomos J N, Setälä H, van der Putten W H, Wal D H. Ecological linkages between aboveground and belowground Biota. Science, 2004, 304(5677) : 1369-1633.

[23] Wang T H, Li H B. Regularities of soil nutrient changing and reformation measures of arable lands in Zhangye City from 1980 to 2004 . Gansu Agricultural Science and Technology, 2007, (11): 38-41.

\section{参考文献:}

[ 1 ] 王芳, 肖洪浪, 苏永中, 范桂萍. 临泽边缘绿洲区盐化草甸开垦后土壤质量演变. 中国沙漠, 2011, 31(3): 723-727.

[ 2 ] 孔祥斌, 张凤荣, 齐伟, 徐艳. 集约化农区土地利用变化对土壤养分的影响一一以河北省曲周县为例. 地理学报, 2003, 58(3): 333-342.

[3] 阳历永, 渠甲源, 吴献花. 不同土地利用方式对土壤养分的影响. 安徽农业科学, 2012, 40(18): 9693-9696.

[ 7 ] 张树清, 孙小风. 甘肃农田土壤氮磷钾养分变化特征. 土壤通报, 2006, 37( 1): 13-18.

[9] 傅伯杰, 郭旭东, 陈利顶, 马克明, 李俊然. 土地利用变化与土壤养分的变化一一河北省遵化县为例. 生态学报, 2001, 21 (6): 926-931.

[10］信忠保, 余新晓, 张满良. 黄土高原丘陵沟壑区不同土地利用的土壤养分特征. 干旱区研究, 2012, 29(3): 379-394.

[11] 傅伯杰, 马克明, 周华峰, 陈利顶. 黄土丘陵区土地利用结构对土壤养分分布的影响. 科学通报，1998，43(22)：2444-2448.

[12] 傅伯杰, 陈利顶, 王军, 孟庆华, 赵文武. 土地利用结构与生态过程. 第四纪研究, 2003, 23(3): 247-255.

[13] 刘全友, 童依平. 北方农牧交错带土地利用类型对土壤养分分布的影响. 应用生态学报, 2005, 16(10)：1849-1852.

[14] 刘文杰, 苏永中, 杨荣, 范桂萍, 杨秋. 黑河中游临泽绿洲农田土壤有机质时空变化特征. 干旱区地理, 2010, 33(2)：170-176.

[15] 赵瑞芬, 张一弓, 张强, 程滨, 张建杰. 不同土地利用方式对土壤养分状况的影响一以太原市为例. 中国农学通报, 2011, 27 (14): 262-266.

[17] 常直海. 土壤普查中常规分析项目和方法. 新疆农业科学, 1979, (2): 31-33.

[18］鲁如坤. 土壤农业化学分析方法. 北京: 中国农业科技出版社, 2000.

[19］王芳, 肖红浪, 苏永中, 范桂萍. 黑河中游边缘绿洲区不同土地利用方式对土壤质量的影响. 干旱区资源与环境, 2010, 24(7): 165-170.

[20］赵哈林，苏永中，周瑞莲. 我国北方沙区退化植被的恢复机理. 中国沙漠, 2006, 26(3): 323-328.

[21] 王根绪, 马海燕, 王一博, 常娟. 黑河流域中游土地利用变化的环境影响. 冰川冻土, 2003, 25(4): 359-367.

[23］王托和, 李宏斌. 1980-2004 年张掖市耕地土壤养分变化及改良措施. 甘肃农业科技, 2007, (11)：38-41. 


\section{ACTA ECOLOGICA SINICA Vol.33, No.19 Oct.,2013(Semimonthly) CONTENTS}

A review of ecosystem services and research perspectives

MA Fengjiao,LIU Jintong, A. Egrinya Eneji (5963)

Sexual interference in non-human primates

YANG Bin, WANG Chengliang, JI Weihong, et al (5973)

Density-dependent effect on reproduction of rodents : a review …............. HAN Qunhua, GUO Cong, ZHANG Meiwen (5981)

Proximate and ultimate determinants of food chain length ............................ WANG Yuyu, XU Jun, LEI Guangchun (5990)

Mechanism of biological control to plant diseases using arbuscular mycorrhizal fungi

LUO Qiaoyu, WANG Xiaojuan, LI Yuanyuan, et al (5997)

Advances in effects of conservation tillage on soil organic carbon and nitrogen

XUE Jianfu, ZHAO Xin, Shadrack Batsile Dikgwatlhe, et al (6006)

Habitat selection of the pre-released giant panda in Wolong Nature Reserve

ZHANG Mingchun, HUANG Yan, LI Desheng, et al (6014)

Activity rhythm and behavioral time budgets of wild Reeves's Pheasant (Syrmaticus reevesii) using infrared camera …................

ZHAO Yuze, WANG Zhichen, XU Jiliang, et al (6021)

The energy budget of tree sparrows Passer montanus in wind different speed and duration

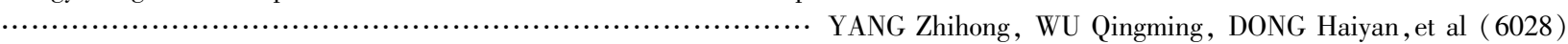

Nest site characteristics of Petaurista caniceps in Baima Snow Mountain Nature Reserve

LI Yanhong, GUAN Jinke, LI Dayong, HU Jie (6035)

Effects of habitat fragmentation on the genetic diversity of Pachycondyla luteipes on islands in the Thousand Island Lake, East

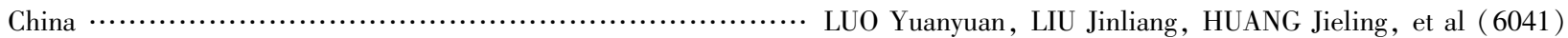

The molecular genetic relationship between the pollinators of Ficus pumila var. pumila and Ficus pumila var. awkeotsang ..............

WU Wenshan, CHEN Youling, SUN Lingli, et al (6049)

The genetic evolutionary relationships of two Eupristina species on Ficus altissima

............................................................ CHEN Youling, SUN Lingli, WU Leilei, et al (6058)

Metal uptake and root morphological changes for two varieties of Salix integra under cadmium stress

WANG Shufeng, SHI Xiang, SUN Haijing, et al (6065)

Effects of phthalic acid on seed germination, membrane lipid peroxidation and osmoregulation substance of radish seedlings ......................................................... YANG Yanjie, WANG Xiaowei, ZHAO Kang, et al (6074)

The morphological and physiological responses of Tamarix ramosissima seedling to different irrigation methods in the extremely arid area

MA Xiaodong, WANG Minghui, LI Weihong, et al (6081)

Response characteristics of photosynthetic and physiological parameters in Ziziphus jujuba var. spinosus seedling leaves to soil

water in sand habitat formed from seashells …................. WANG Rongrong, XIA Jiangbao, YANG Jihua, et al (6088)

Effects of ceramsite mulching on soil water content, photosynthetic physiological characteristics and growth of plants …...............

TAN Xuehong, GUO Xiaoping, ZHAO Tingning (6097)

Dynamics of tannin concentration and nutrient resorption for branchlets of Casuarina equisetifolia plantations at different ages .........

YE Gongfu, ZHANG Shangju, ZHANG Lihua, et al (6107)

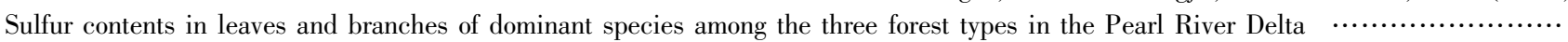

PEI Nancai, CHEN Bufeng, ZOU Zhijin, et al (6114)

Impacts of arbuscular mycorrhizal fungi and phosphorus on growth dynamics of Bauhinia faberi seedlings

SONG Chengjun, QU Laiye, MA Keming, et al (6121)

Characteristics of ion accumulation and seed germination for seeds from plants cultured at different concentrations of nitrate nitrogen and salinity

ZHOU Jiachao, FU Tingting, ZHAO Weiwei, et al (6129)

Physio-ecological effects of endophyte infection on the host grass with elevated $\mathrm{CO}_{2}$

Effects of pretreatment on germination of Typha domingensis and Phragmites australis

SHI Zhibing, ZHOU Yong, LI Xia, et al (6135)

MENG Huan, WANG Xuehong, TONG Shouzheng, et al (6142)

Transfer characteristics of cadmium from soil to Salix $\times$ aureo-pendula ….. ZHANG Wen, WEI Hong, SUN Xiaocan, et al (6147) Effect of Close-to-Nature management on the natural regeneration and species diversity in a masson pine plantation

LUO Yinghua, SUN Dongjing, LIN Jianyong, et al (6154)

Population dynamics and seed banks of the threatened seagrass Halophila beccarii in Pearl Bay, Guangxi

QIU Guanglong, FAN Hangqing, LI Zongshan, et al (6163)

Effects of biological crusts on dew deposition and evaporation in the Southern Edge of the Mu Us Sandy Land, Northern China ...... , Z

Life history characteristics and spatial distribution of Populus pruinosa population at the upper reaches of Tarim River $\cdots . . . . . . . . . . .$. .

Interactive effects of short-term nitrogen enrichment and simulated grazing on ecosystem respiration in an alpine meadow on the Tibetan Plateau ZONG Ning, SHI Peili, JIANG Jing, et al (6191) 
The correlation between soil water salinity and plant community distribution under micro-topography in Songnen Plain , W

Comparison of TSP, $\mathrm{PM}_{2.5}$ and their water-soluble ions from both inside and outside of Dafushan forest park in Guangzhou

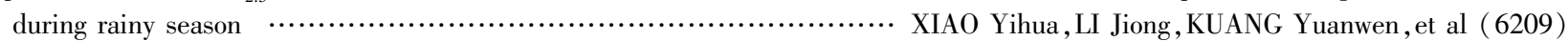

Fish community ecology in rocky reef habitat of $\mathrm{Ma}^{\prime}$ an Archipelago II . Spatio-temporal patterns of community structure

WANG Zhenhua, ZHAO Jing, WANG Kai, et al (6218)

Interannual variation in the population dynamics of snailfish Liparis tanakae in the Yellow Sea

CHEN Yunlong, SHAN Xiujuan, ZHOU Zhipeng, et al (6227)

Spatial and temporal variation of soil macro-fauna community structure in three temperate forests

... LI Na, ZHANG Xueping, ZHANG Limin (6236)

Community structure and species biodiversity of fig wasps in syconia of Ficus superba Miq. var. japonica Miq. in Fuzhou

CHEN Youling, CHEN Xiaoqian, WU Wenshan, et al (6246)

Marine ecological capital: valuation methods of marine ecosystem services …. CHEN Shang, REN Dachuan, XIA Tao, et al (6254)

Geomorphologic regionalization of China aimed at construction of nature reserve system ….......... GUO Ziliang, CUI Guofa (6264)

Impact of ecological vegetation construction on the landscape pattern of a Loess Plateau Watershed ....

YI Yang, XIN Zhongbao, QIN Yunbin, et al (6277)

Spatial heterogeneity of soil moisture across a cropland-grassland mosaic: a case study for agro-pastural transition in north of Chin

WANG Hongmei, WANG Zhongliang, WANG Kun, et al (6287)

The regional diversity of changes in growing duration of spring wheat and its correlation with climatic adaptation in Northern

China

Response of soil physical-chemical properties to rocky desertification succession in South China Karst ................................

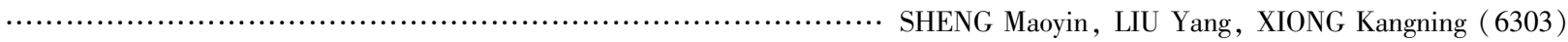

Prediction of the effects of climate change on the potential distribution of mire in Northeastern China

HE Wei, BU Rencang, LIU Hongjuan, et al (6314)

Soil nitrogen mineralization and associated temperature sensitivity of different Inner Mongolian grasslands

ZHU Jianxing, WANG Qiufeng, HE Nianpeng, et al (6320)

Effects of land use on soil nutrient in oasis-desert ecotone in the middle reach of the Heihe River

MA Zhimin, LÜ Yihe, SUN Feixiang, et al (6328)

Assessment on heavy metal pollution status in paddy soils in the northern Chengdu Plain and their potential ecological risk

QIN Yusheng, YU Hua, FENG Wenqiang, et al (6335)

Relationship between the temporal-spatial distribution of longline fishing grounds of yellowfin tuna (Thunnus albacares) and the thermocline characteristics in the Central Atlantic Ocean …......... YANG Shenglong, MA Junjie,ZHANG Yu, et al (6345)

Biological nitrogen fixation in the upper water column in the south Taiwan Strait during summer 2011

torage and drivers of forests carbon on the Beichangshan Island of Miaodao Archipelago

LIN Feng, CHEN Min, YANG Weifeng, et al (6354)

SHI Honghua, WANG Xiaoli, WANG Ai, et al (6363)

Impact of changes in vegetation types on soil $\mathrm{C}$ mineralization and associated temperature sensitivity in the Changbai Mountain

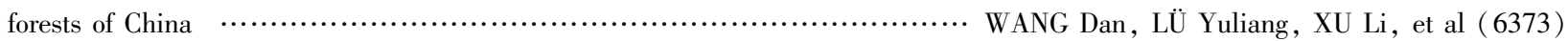

Analysis of relationship between genetic structure of Chinese Pine and mountain barriers

MENG Xiangxiang, DI Xiaoyan, WANG Mengben, et al (6382)

Soil organic carbon interpolation based on auxiliary environmental covariates:a case study at small watershed scale in Loess Hilly

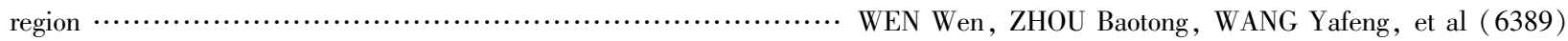

Eco-management benefit analysis of industrial resources from life cycle perspective: a case study of a virtual symbiosis network .

The game analysis between poverty and environment in ecologically fragile zones $\cdots$ QI Xinhua, YE Shilin, CHENG Yu, et al (6411)

The coupling development of economy and environment under the background of World Expo in Shanghai 


\section{《生态学报》2013 年征订启事}

《生态学报》是由中国科学技术协会主管, 中国生态学学会、中国科学院生态环境研究中心主办的生态学 高级专业学术期刊,创刊于 1981 年,报道生态学领域前沿理论和原始创新性研究成果。坚持“百花齐放,百家 争鸣” 的方针, 依靠和团结广大生态学科研工作者, 探索生态学奥秘, 为生态学基础理论研究搭建交流平台, 促进生态学研究深人发展, 为我国培养和造就生态学科研人才和知识创新服务、为国民经济建设和发展服务。

《生态学报》主要报道生态学及各分支学科的重要基础理论和应用研究的原始创新性科研成果。特别欢 迎能反映现代生态学发展方向的优秀综述性文章; 研究简报; 生态学新理论、新方法、新技术介绍; 新书评价和 学术、科研动态及开放实验室介绍等。

《生态学报》为半月刊,大 16 开本, 300 页, 国内定价 90 元/册, 全年定价 2160 元。

国内邮发代号: 82-7,国外邮发代号: M670

标准刊号:ISSN 1000-0933 CN 11-2031/Q

全国各地邮局均可订阅，也可直接与编辑部联系购买。欢迎广大科技工作者、科研单位、高等院校、图书 馆等订阅。

通讯地址: 100085 北京海淀区双清路 18 号 电话: (010)62941099; 62843362

E-mail: shengtaixuebao@ rcees.ac.cn网址: www.ecologica.cn

本期责任副主编 陈利顶 编辑部主任 孔红梅 执行编辑 刘天星 段 靖

\author{
生 态 学 报 \\ (SHENGTAI XUEBAO) \\ (半月刊 1981 年 3 月创刊)
}

第 33 卷 第 19 期 (2013 年 10 月)

\section{ACTA ECOLOGICA SINICA}

( Semimonthly, Started in 1981)

Vol. 33 No. 19 (October, 2013)

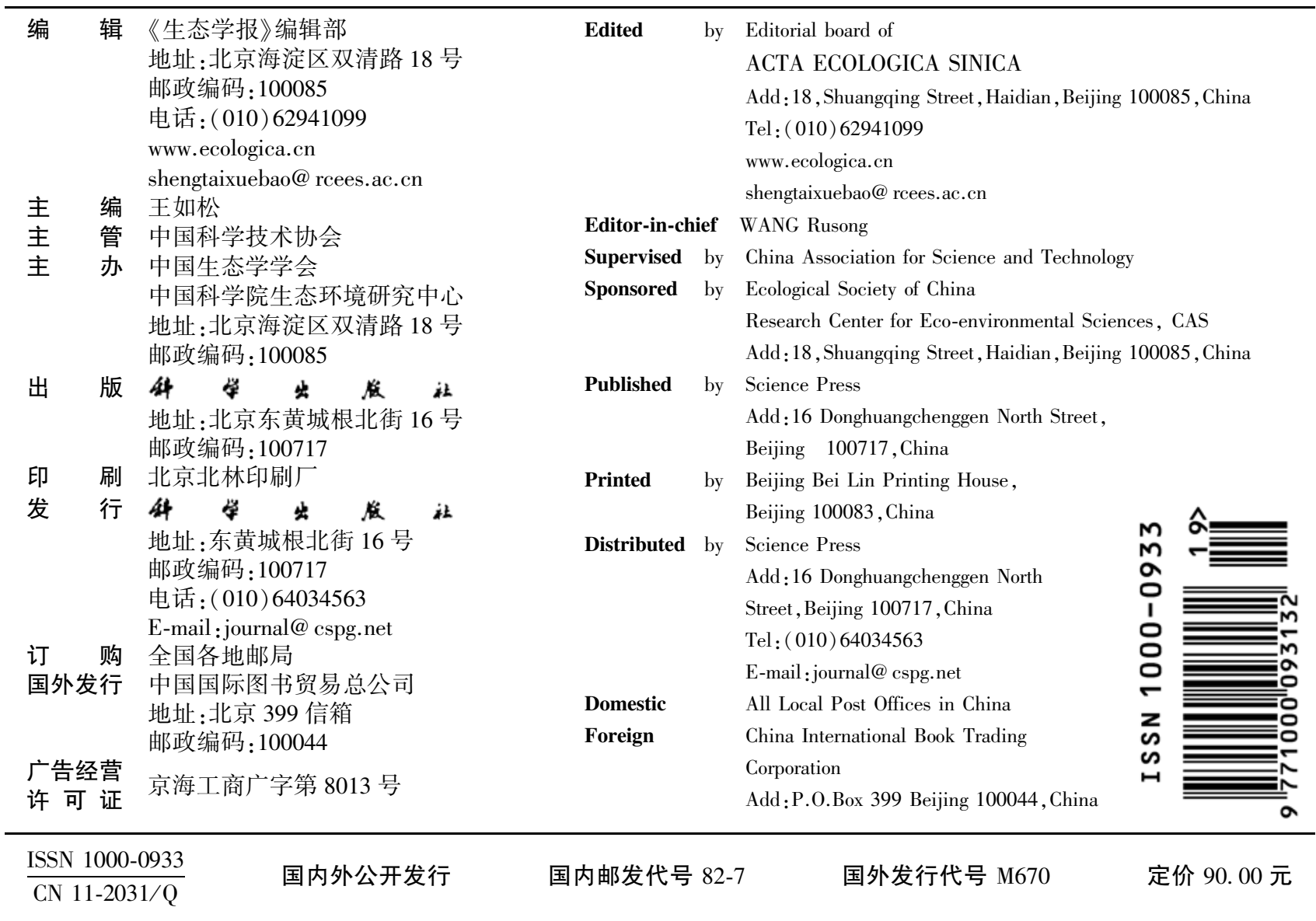

